UDC 347.918(460)

CERIF: S144

\author{
Maria del Pilar Perales Viscasillas, $\mathrm{PhD}^{*}$
}

\title{
SOME SPECIFIC ISSUES ABOUT ARBITRABILITY IN SPAIN: BACK TO THE PAST?
}

The object of this paper on arbitrability in the Spanish legal system, is to explore whether the general rule on objective arbitrability, based upon the free disposition of the rights which under the Spanish Arbitration Law translates a general principle pro arbitration and arbitrability, is threatened by doctrinal interpretations, legal rules or recent judicial decisions, where arbitrability has been constrained. This is particularly the case in the field of regulated sectors, where the arbitrability of disputes is quite controversial and complex, and the key institutions meet: arbitration, state justice, and decision-making powers attributed to a regulatory body, in the case of Spain, the National Commission on Markets and Competition (CNMC).

Key words: Arbitration. - Arbitrability. - Spain. - Regulated sectors.

\section{DOMESTIC AND INTERNATIONAL TRENDS CONCERNING ARBITRABILITY}

It is clear that internationally and domestically there is an increasing tendency to increase arbitrability matters, ${ }^{1}$ despite the fact that in some domestic legal systems there are always criteria to suggest and challenge whether a matter is arbitrable. Generally, domestic laws consider

* Professor, Carlos III University of Madrid Faculty of Law, pperales@der-pr. uc3m.es. This paper is part of the Research Project of the National Plan I+D, by the Ministry of Economy and Competitiveness of Spain (DER2016-78572-P).

1 C. Trabuco, M. Franç̧a Gouveia, "A Arbitrabilidade das questões de concorrência no direito portugués: The meeting of the two black arts", Estudos em homenagem ao Professor Doutor Carlos Ferreira de Almeida, Almedina 2011, 449; N. Bouza Vida, "La arbitrabilidad de los litigios en la encrucijada de la competencia judicial internacional y de la competencia arbitral", Revista Española de Derecho Internacional 2/2000, 373-375. 
arbitrability under general rather than exhaustive provisions, frequently changes in the criteria to be applied to arbitrability issues over time. ${ }^{2}$ Some national laws provide that all rights or matters that the parties "may freely dispose of" ${ }^{3}$ or "property issues" 4 may be subject to arbitration. ${ }^{5}$ Also, many statutes link arbitrability with the transaction, and thus the matters that are the subject of a transaction may also be subject to arbitration. ${ }^{6}$ These general clauses require significant specification and interpretation in order to assess which of the specific issues that are subject to arbitration are arbitrable. Doctrinal and case law construction is also identified in the few statutes where this issue is not addressed.However, even if considered an ideal moment for arbitrability issues at an international level, State legislators or judges may for different reasons, based on political, economic or legal needs, seek to protect certain interests of individuals or certain eco-

2 Portuguese law offers an interesting development. Under the repealed Law $31 / 86$ on Arbitration, the criterion of free availability was used, as is done by Spanish law, and it was already understood that the criterion of patrimoniality was broader (D. M. Vicente, Law of Voluntary Arbitration Annotated, Almedina- Coimbra, 2017, 30; L. de Lima Pinheiro, Arbitragem Transnacional. A determinação do estatuto da arbitragem, Almedina, Coimbra 2005, 105). However, under the current legal provision, where the legal criterion is the patrimoniality of the matter, what is a patrimonial matter is controversial and different interpretations arise including an identification with the former criterion. For a discussion under current law see: A. Menezes Cordeiro, Tratado da Arbitragem. Comentário à Lei 63/2011, de 14 de Dezembro, Almedina-Coimbra 2015, 94.

3 Article 2 (1) of the Spanish Arbitration Act (B.O.E. 2003, 60); Article 2059 of the French Civil Code [C. CIV.]; Articles 808 and 1966(2) of the Italian Civil Procedure Code [C.p.c.]; Article 1 of the Peru Arbitration Act (2008); Organization for the Harmonization of Business Law in Africa (OHADA), Uniform Act of Arbitration (1999); Art. 1 of the Arbitration Law of Angola.

4 Article 177(1) of the Swiss Private International Law, Dec. 18, 1987, RO 1776; German Code of Civil Procedure Jan. 30, 1877, Article 1030(1) of the German Reichsgesetzblatt.

5 In Brazil, Law 9.307/1996 on Arbitration (Lei No. 9.307, de 23 de Setembro de 1996, Diário Oficial da União [D.O.U.] (t. 1): de 24.9.1996 (Braz.)) refers to Direitos patrimoniais disponiveis as a criterion for determining arbitrability, combining two of the most popular criteria found in domestic laws.

About the meaning of Direitos patrimoniais disponiveis, scholars in Brazil: H. Malheiros Duclerc Verçosa, "Doze anos da lei de arbitragem: alguns aspectos ainda relevantes", Aspectos da arbitragem institucional. 12 anos da Lei 9.307/1996, Malheiros editores 2008,16 , refers to patrimonial disputes available as all those involving quantifiable interests in money, in respect of which the parties are free to compromise; and C. M. C. Penteado, Jr., "Os Direitos patrimoniais disponíveis e as regras de julgamento na arbitragem", Revista de Arbitragem e Mediação 20/2009, 80-85, considers, everything that may be an object of transaction, which equates to the availability of the right or the possibility of resignation to an existing right.

6 Zivilprozessordnung [ZPO] [Civil Procedure Statute] Reichgesetzblatt [RGBl] No. 113/1895 (Austria); Article 2 of the Finnish Arbitration Law (Oct. 23 1992); Article 13 (1) of the Japanese Arbitration Law, Law No. 138 of 2003; Article 1 (a) of the § Lag om skiljeförfarande (Svensk författningssamling [SFS] 1999:116) (Swed.). 
nomic sectors by establishing limits to arbitrability. Domestic cases on arbitrability are seen from time to time in different jurisdictions. Even if we consider typical commercial areas - intra-corporate disputes, securities, intellectual property, fair and unfair competition, distribution contracts, financial contracts, insurance, transport, insolvency, or regulated economic sectors (including energy) - the different approaches to arbitrable subject matters taken by domestic laws, scholars and case law has created uncertainty. There are different reasons for adopting limitations such as public policy, the need to protect the essential conditions of a given market, or the idea that there is a weaker party and thus the need to protect it because of the unequal bargaining power of the parties and the imposition of arbitration by one of them. This is the case seen in certain countries: to protect consumers, commercial agents, distributors, ${ }^{7}$ or franchisees, for example.

Contrarily, no discussion about arbitrability is needed if the very same State, in order to enhance arbitration or to facilitate the access to justice, declares certain matters to be mandatorily subject to arbitration and therefore it is clear that there is no discussion about arbitrability. ${ }^{8}$ The difference in perspectives adopted at domestic levels on arbitrability is due to a certain extent to the lack of a uniform international rule on arbitrability. Neither the 1985 UNCITRAL Model Law on International Commercial Arbitration (MAL) ${ }^{9}$ nor its 2006 revision ${ }^{10}$ contain a provision dealing with arbitrability. The legislative history is clear on this point:

"The prevailing view was that the Model Law should not contain a provision delimiting non-arbitrable issues."11

7 Distribution contracts are commercial contracts. Traditionally, commercial contracts may be subject to arbitration without the need to impose limitations. The rationale behind this general rule is that in commercial contracts, both parties share equal contracting power and thus there is no need to impose limitations. Among others: J. Kleinheisterkamp, "The Impact of Internationally Mandatory Law on the Enforceability of Arbitration Agreements", LSE Law Society and Economic Working Papers 22/2009, 1-2, http:// ssrn.com/abstract $=1496923$, last visited 6 November 2017 (see for with special reference to distribution contracts); S. Kröll, "The 'Arbitrability' of disputes arising from Commercial Representation", Arbitrability. International \& Comparative Perspectives, Wolter Kluwers, 2009, paras. 16-3; P. Perales Viscasillas, "The Good, the Bad, and the Ugly in Distribution Contracts: Limitation of Party Autonomy in Arbitration?", Penn. St. J.L. \& Int'l Aff 4/2015, 213-241.

8 C. Trabuco, M. Francça Gouveia, 456.

9 http://www.uncitral.org/pdf/english/texts/arbitration/ml-arb/06-54671_Ebook. $p d f$, last visited 6 November 2017.

10 http://www.uncitral.org/pdf/english/texts/arbitration/ml-arb/07-86998_Ebook. $p d f$, last visited 6 November 2017.

11 A/CN.9/216, 23 March 1982, No. 30. http://daccess-dds-ny.un.org/doc/UN DOC/GEN/V82/252/94/PDF/V8225294.pdf?OpenElement, last visited 6 November 2017. 
Despite that conclusion, arbitrability was repeatedly included in the agenda for the MAL revision. ${ }^{12}$ The UNCITRAL Working Group II considered the differences in domestic laws and the uncertainties derived from distinct legal solutions towards arbitrability to be problematic for international arbitration. ${ }^{13}$ Although the general trend in domestic laws is a broader approach to submitting to arbitration matters that have been traditionally outside of its scope, incorporation of an arbitrability rule within the MAL could be deemed both necessary and possible. First, consideration should be given to the lack of uniform solutions in the law. Due to the MAL's silence on the issue, it is clear that there is no uniform approach to arbitrability. Second, arbitrability is an important issue to be analyzed both by the arbitrators during the arbitration procedure (ex officio) and by the courts at the beginning, if an exception of competence is presented, ${ }^{14}$ or after the arbitration (also ex officio as arbitrability is a

12 A/CN.9/216, 23 March 1982, No. 30-31. http://daccess-dds-ny.un.org/doc/UNDOC/GEN/V82/252/94/PDF/V8225294.pdf? OpenElement, last visited 6 November 2017. It was also considered by the Commission it its $36^{\text {th }}$ session (Vienna, 30 June -11 July 2003), http://daccess-dds-ny.un.org/doc/UNDOC/GEN/V82/252/94/PDF/V8225294.pdf? OpenElement, last visited 6 November 2017, 37 $7^{\text {th }}$ (New York, 14-25 June 2004) http:// daccess-dds-ny.un.org/doc/UNDOC/GEN/V04/562/43/PDF/V0456243.pdf?OpenElement, last visited 6 November 2017, and $38^{\text {th }}$ (Vienna, 4-15 July 2005), http://daccess-dds-ny. un.org/doc/UNDOC/GEN/V05/868/63/PDF/V0586863.pdf?OpenElementsessions, last visited 6 November 2017). In particular, the Commission noted that priority consideration might be given to the issue of arbitrability of intra-corporate disputes, as well as arbitrability in the fields of immovable property, insolvency and unfair competition, see: A/ CN.9/610, 5 April 2006, No. 6, at http://daccess-dds-ny.un.org/doc/UNDOC/GEN/ V06/526/16/PDF/V0652616.pdf?OpenElement, last visited 6 November 2017; and A/61/17, No. 183, http://daccess-dds-ny.un.org/doc/UNDOC/GEN/V06/558/15/PDF/V06 55815.pdf? OpenElement, last visited 6 November 2017.

13 A/CN.9/610, 5 April 2006, No. 8, http://daccess-dds-ny.un.org/doc/UNDOC/ GEN/V06/526/16/PDF/V0652616.pdf? OpenElement, last visited 6 November 2017 .

14 In regard to this case, recently the High Supreme Court of Spain, 27 June 2017 (No. 3292/2014) analysed the two different criteria. The first would be the so-called strong thesis of the kompetenz-kompetenz principle, which is the one held by the appellant, according to which the judicial body's action in case of a declinatory approach should be limited to superficial analysis, the existence of the arbitration agreement, and, if there is such an agreement to consider the declination, for the arbitrators to decide on their own jurisdiction. Only by way of subsequent action to annul the award (which could be a partial award, in which the arbitrator or arbitrators were limited to decide on their own jurisdiction), the judicial bodies could review the decision of the arbitrators on their jurisdiction. The second would be the so-called weak thesis, according to which the judicial body before which the declination of jurisdiction for submission to arbitration is considered must carry out a complete examination of the validity, effectiveness and applicability of the arbitration agreement. Thus, if the judge considers that the arbitration agreement is invalid, is not effective or is not applicable to the issues subject to the claim, the court will reject the declination and will continue to hear the litigation. This court considers that there is no reason to uphold the strong thesis of the kompetenz-kompetenz principle in our legal system and to limit the scope of the judge's knowledge when he resolves the declination of jurisdiction by submission to arbitration. 
ground for setting aside an award (Art. $34 \mathrm{MAL}$ ) and for denying its enforcement (Art. $36 \mathrm{MAL}$ and New York Convention Art. V.2(a)). Additionally, the fact that general and broad definitions are present in many arbitration laws does not help to build a uniform solution, since arbitrability in specific areas is subject to scholarly interpretation and judicial decisions that may be based on national conceptions, limiting arbitrability of the subject matter of the dispute. Furthermore, legal certainty is rarely achieved due to the fact that many states address arbitrability in specific laws.In terms of finding a uniform solution for an arbitrability rule, the Working Group II foresaw a possible design of the rule on arbitrability: a general formula and a uniform list of exceptions. ${ }^{15}$ This kind of solution would be easy to implement and would contribute greatly to uniformity in this area. The UNCITRAL could take a leading role in creating a uniform and international solution, calling attention to the need to strengthen the boundaries of arbitrability to states that are reluctant to do so. However, in terms of uniformity, the mentioned solution would not suffice. Further consideration should be given to the design of more complex rules for specific subject matters that are highly controversial under domestic laws. To provide one example, intra-corporate disputes are quite a complex area, where one encounters traditional misconceptions, arguments and limitations against arbitration: imperative rules, public order, the impact of third party rights, and the exclusive competence of state courts. The problems, however, are not limited to arbitrability; procedural aspects also need to be studied, including the impact of arbitration of intra-corporate disputes on third parties, the effect of the award on commercial registries, confidentiality versus transparency, and the permissibility of arbitration in equity.As this brief survey of problems shows, a general formula on arbitrability would not be sufficient to tackle all of the issues that arise from the possibility of submitting intra-corporate disputes to arbitration. Specially tailored provisions would be needed to provide uniformity and certainty in this area. A work by the UNCITRAL in the area of arbitrability of commercial disputes would help to fill an important gap in the MAL and to achieve desired uniformity, international

15 A/CN.9/610, 5 April 2006, No. 8, http://daccess-dds-ny.un.org/doc/UNDOC/ GEN/V06/526/16/PDF/V0652616.pdf?OpenElement, last visited 6 November 2017: "Work might be geared, for example, towards formulating a uniform provision setting out three or four issues that were generally considered non-arbitrable and calling upon States to list any other issues that are regarded as non-arbitrable by the State. At the same time, concerns were expressed that any national listing of non-arbitrable issues might be inflexible and therefore counter-productive. It was said that the question of arbitrability was subject to constant development (including through case law) and that some States might find it undesirable to interfere with that development (see below, para. 13)." This simple solution was already in place in 1982: "it was noted that further thought could be given to the possibility of devising a general formula to determine non-arbitrability along the following lines -a subject matter is arbitrable if the issue in dispute can be settled by agreement of the parties" (A/CN.9/216, 23 March 1982, No. 30-31). 
consensus, and legal certainty in the arbitration world. Until that moment, we still have to struggle with the different views of arbitrability in domestic legal systems. The object of this paper is to explore whether the general principle pro arbitration and arbitrability in Spain is threatened by doctrinal interpretations and recent judicial decisions where arbitrability has been constrained.

\section{AN OVERVIEW OF ARBITRATION IN SPAIN: DOMESTIC AND INTERNATIONAL}

The law in force in Spain is Law 60/2003 on Arbitration, of 23 December, 2003, which follows to a great extent, although with some departures, the 1985 UNCITRAL Model Law on International Commercial Arbitration (MAL). The Procedural Law of 2000 also contains several provisions on arbitration. The Spanish Arbitration Law is a general law for arbitration and thus private legal issues, including both commercial and civil transactions, are included, with the exception of labour law disputes, which are excluded from the scope of the aforementioned Law. One of the main objectives of the new law was to promote Spain as a seat for international arbitration. The purposes of both the 2003 Arbitration Law and the modifications operated on it by Law $11 / 2011^{16}$ are in line with the objective to promote and develop arbitration in Spain and to attract international arbitration:

a) to contribute to improve the ADR methods and to definitely launch arbitration in Spain;

b) to improve the conditions for establishing international arbitration in Spain and to increase legal security of arbitration, in order to enhance arbitral proceedings particularly from an international perspective;

c) to strength institutional arbitration;

d) to clarify doubts in relation to certain matters, such as corporate arbitration and arbitration within insolvency proceedings; and

e) to increase legal security and efficiency of arbitral proceedings. As opposed to the old Law from 1988, which considered a dual system depending on the domestic or international character of the arbitration, the 2003 Law on Arbitration unifies the rules of both types of arbitrations. Therefore, while the preference is the

16 By Law 11/2011, 20 May 2011, the 2003 Arbitration Act is modified with effect from June 10, 2011. See Law 11/2011, 20 May 2011, that reforms Law 60/2003, 23 December, 2003, on Arbitration and institutional arbitration in the General Administration of the State (BOE, núm.121, 21 May 2011). 
so-called monist system, there are still a few, but clearly justifiable, special rules that have been adopted for international arbitration. Furthermore, the Law sets forth a general system applicable to any kind of arbitration lacking special arbitration rules, and even in such cases recourse may be made to the supplementary law (Art. 1.3 LA). Labour arbitration is excluded. The Law defines "international" arbitration very broadly and flexibly, in accordance with the Model Law. According to the Spanish Arbitration Law, an arbitration is "international" if any of the following circumstances have been met: if, at the time the arbitration agreement is made, the parties have their legal residences in different countries; if the place of arbitration, as determined in the arbitration agreement, the place of the performance of a substantial part of the legal obligations from which the dispute arises, or the place where the dispute has its closest ties is situated outside of the country where the parties have their legal residences; or if the legal relationship from which the dispute arises affects the interests of international trade. The last criterion is a new one, when compared to those from the Model Law, but it is a criterion that is widely developed in other legal systems. Following the Model Law, the Law also avoids the confusion that multiple domiciles of a party could cause in determining whether the arbitration is international or not. The national or international character of the arbitration, however, is distinct from the domestic or international character of the award.

The Arbitration Law applies to all arbitral proceedings, whether domestic or international, where the place of arbitration is within Spanish territory, but there can be extraterritorial application of some of the rules: judicial granting of interim measures; an order enforcing the award; exequatur of foreign arbitral awards; the form and contents of the arbitration agreement, except when the arbitration agreement appears in a standardform contract; objections to jurisdiction; and interim measures granted by the arbitrators. The international character of the arbitration, as mentioned, determines the application of special rules, the more relevant among these being: the validity of the arbitration agreement (Art. 9.6), and the substantive rules applicable to the contract (Art. 34.2). Spain is also a party to the 1958 New York Convention on the Recognition and Enforcement of Foreign Arbitral Awards, the Geneva Convention on the Execution of Foreign Arbitral Awards of 1927, and the Washington Convention on the Settlement of Investment between States and Nationals of Other States of 1965. Spain has also signed bilateral on the recognition and enforcement of foreign decisions, including arbitral awards, and more 
than 50 BITs that include arbitration clauses. Special arbitration rules and even arbitral systems are included in different laws in Spain. The most important being:

a) consumer arbitration: a special system for consumer arbitration is presently contained in Royal Decree 231/2008, of 15 February, on Arbitral Consumer System (Sistema Arbitral de Consumo), which supersedes regulation 636/1993, of 3 May; ${ }^{17}$

b) corporate disputes: new articles 11 bis $^{18}$ and ter have been included in the modification of the 2003 Arbitration Law by Law 11/2011, of 20 May, considering the possible inclusion of arbitration clauses in the corporate bylaws, and thus confirming what was the old approach in Spain. ${ }^{19}$ For example, the Regulation of the Commercial Registry was modified on 16 March 2007 to introduce a provision where the bylaws of all types of corporations might include a provision on arbitration (Art. 114.2 and Art. 175.2). ${ }^{20}$ These rules state that the bylaws can include an arbitration clause for intra-corporate disputes among the shareholders, or between the shareholders and the corporation or its bodies. Also, the Law on Professional Entities (Ley de Sociedades Profesionales) of 16 March 2007 allows for the arbitration of, inter alia, disputes related to the withdrawal, squeezing-out, or determining of the equity interest in a professional entity.Spain has a long tradition in corporate arbitration and thus to facilitate the submission of intra-corporate disputes to arbitration, the interested bodies have drafted model arbitration clauses as well as special

17 See: M. Richard González, I. Riaño Brun, J. M. Rifá Soler, Estudios sobre arbitraje de consumo, Thomson Reuters, 2011; P. Perales Viscasillas, "Los convenios arbitrales con los consumidores (La modificación del art. 57.4 TRLGDCU por la Ley 3/2014 de 27 de marzo)", La Ley Mercantil 7/2014, 1-22.

18 Article 11 bis of the Law of Arbitration: "1. Companies may submit disputes arising within them to arbitration.

2. Insertion into a company's articles of association of a clause providing for submission of disputes to arbitration shall require favourable vote representing at least two thirds of the share capital of the company.

3. A company's articles of association may provide that any challenge to corporate resolutions by members or directors shall be subject to the decision of one or more arbitrators, designating an arbitration institution to administer the arbitration proceedings and appoint the arbitrator(s)."

In Peru (MAL country), through the Arbitration Act, the General Law on Corporation is modified as to include a provision dealing with intra-corporate disputes (see Art. 48 of Law No. 26887).

19 P. Perales Viscasillas, Arbitrabilidad y Convenio arbitral (Ley 60/2003 de Arbitraje y Derecho Societario), Thomson-Aranzadi, Navarra, 2005.

20 In regard to condominium division, where arbitration is very popular, arbitration clauses contained in the bylaws are considered valid. See Madrid Appellate Court, 26 September 2006. 
procedural rules to be incorporated into corporate bylaws or articles of incorporation, as well as model clauses and procedural rules for arbitral institutions. $^{21}$ - intellectual property rights: Royal Decree 1/1996 on the Intellectual Property Rights Law, of 12 April, set up an Intellectual Property Rights Commission that can arbitrate disputes between the participants in this sector;

c) trademarks and industrial designs: Law 17/2001 on Trademarks, of 7 December, and Law 20/2003 on Industrial Designs, ${ }^{22}$ of 7 July, establish the right to arbitrate disputes that may arise during the process of registering a trademark or a design. ${ }^{23}$ As noted, while not a purely private legal issue, it is an issue that is part of an administrative procedure, albeit between private parties. Therefore, in such cases arbitration supersedes administrative recourse and is the final, binding award on the parties. ${ }^{24}$ The existence of specific legal provisions in the area of validity of industrial property rights is rare but there are some exceptions. ${ }^{25}$ Of course, regular private arbitration between parties, having to do with the usual contractual issues related to trademarks or industrial design, is also available ${ }^{26}$

21 See Report on Corporate Arbitration and Model Arbitration clause offered by the Spanish Club of Arbitration, http://www.clubarbitraje.com/files/docs/cea_Arbitraje_ Societario.pdf, last_visited 6 November 2017 and the new rules for corporate arbitration included in the Rules of Arbitration of the Court of Arbitration of Madrid (in force from 1 March 2015, Art. 52).

In fact, such model clauses and special procedural rules are increasingly common. Examples include the Mauritius International Arbitration Act (model clause), $h t t p: / / w w w$. wipo.int/edocs/lexdocs/laws/en/mu/mu020en.pdf, last visited 6 November 2017, and the model arbitration clause and supplementary rules offered by the DIS (German Institution for Arbitration), http://www.disarb.org/en/16/regeln/dis-supplementary-rules-for-corpora te-law-disputes-09-srcold-id15, last visited 6 November 2017.

22 BOE, No. 294, December 8, 2001; and BOE, No. 162, July 8, 2003.

23 Article 28: 1. The persons concerned may submit to arbitration the matters in dispute arising in connection with the procedure for the registration of a trademark in accordance with the provisions of this Article.

2. The arbitration may only deal with the relative prohibitions provided for in Articles 6.1.b), 7.1.b), 8 and 9 of this Law. In no case may questions be submitted to arbitration regarding the occurrence or not of formal defects or absolute prohibitions of registration.

24 P. Perales Viscasillas, "Arbitrabilidad de los derechos de la propiedad industrial y de la Competencia", Anuario de Justicia Alternativa, Derecho Arbitral 6/2005, 11-76.

25 See: A. De Miguel Asensio, "Alcance de la arbitrabilidad de los litigios sobre derechos de propiedad industrial”, Arbitraje 1/2014, 88-90, considering also the expansion of arbitrability in this area.

26 Article 40: The owner of a registered trademark may bring before civil courts or criminal proceedings against those who injure his right and demand the necessary measures to safeguard it, without prejudice to submission to arbitration, if possible. 
d) patents: Different to the old patent law, which was silent on the possible submission of disputes to arbitration and thus scholars held different views on this, the Law 24/2015 on Patents, 24 July, (BOE, $n^{\circ} 177$, 25 July 2015) considers the possible arbitration in this area although with some restrictions to arbitrability;

e) transport law: Law 16/1987, of 30 July, contemplates a special system under the Transport Arbitration Board and its regulation;

f) probate proceedings: The arbitration law includes a special rule that weighs the validity of arbitration, instituted by testamentary disposition, which resolves differences among heirs-apparent or beneficiaries over issues concerning the distribution or administration of an estate (Art. $10)$;

g) administrative contracts: Royal Legislative Decree 3/2011, 14 November, on Contracts made by the Public Administration as well as its predecessor (Law 30/2007, of 13 October) stipulates that these contracts may be subject to arbitration when the entities of the public sector do not have the character of a public administration institution. Therefore, private administrative contracts - but not public administrative contracts may be subject to arbitration under the 2003 Law on Arbitration (Art. 50, and Additional Disposition 1, $\mathrm{n}^{\circ} 3$ in relation to international contracts) without the need of previous approval to submit disputes to arbitration, ${ }^{27}$

h) regulated sectors: There are several trade sectors, formerly subject to the monopoly of the State, that are now partly or completely in the

27 Also at a comparative level, there are countries which also have evolved towards an opening for arbitration in public contracts. See, for Brazil, where three main positions are considered as to the conceptual understanding of arbitrability. The first is to revert the old prohibitive rule in such a way that the existence of a presumption of the arbitrability of contractually regulated state rights and interests can be maintained; the second is to consider that arbitration is prohibited only when judicial intervention is necessary; and third is that a general rule on arbitrability has the exception for issues that involve essential public interests. Hence the opening of arbitration in the area of administrative law, also fostered by the new guidelines in the negotiation-contractual activity of the Administration: E. Talamini, "A (in) disponibilidade do interesse público: conseqüências processuais (composições em juízo, prerrogativas processuais, arbitragem e ação monitória", Revista de Processo 128/2005, 69-71; G. H. Justino de Oliveira, "A Arbitragem e as Parcerias Público-Privadas", Revista de Direito Administrativo, 2005, 248; D. Zimmermann, "Alguns aspectos sobre a arbitragem nos contratos administrativos à luz dos principios da efíciencia e do acceso à justiça, por uma nova concepção do que seja interesse público" Revista de Arbitragem e mediaçao, 2/2007, 69-92; L. Da Gama e Souza, Jr., "Sinal verde para a arbitragem nas parcerias público-privadas (A Construção de um novo paradigma para os contratos entre o Estado e o Investidor privado)", Revista de Direito Administrativo 2/2005, 134-140; and G. Ettore Nanni, Direito Civil e Arbitragem, Atlas, Sao Paulo, 2014, 99-100. 
hands of the private sector - for example: energy, telecommunications, and postal services. Initially, under the special rules of these sectors, and also in the general law on free competition, ${ }^{28}$ a special arbitration system was considered, and thus an open view in regard to arbitrability was considered. ${ }^{29}$ However, the system was in the hands of special regulatory bodies, without the prejudice of private arbitration.

Since 2013, all the arbitration systems in the regulated sectors have been integrated into a single one, under the newly created National Commission on the Markets and Competition. It is interesting to mention that the arbitration system adopts the UNCITRAL Arbitration Rules (UAR) as institutional rules in regard to disputes under the new body: the National Commission on the Markets and Competition. ${ }^{30}$ The arbitration procedure would be subject to UAR or, as the case may be, to rules laid down by the National Commission. ${ }^{31}$ In this paper we will further consider certain issues related to arbitration and arbitrability in the area of the regulated sectors.

28 Formerly contained under Law 15/2007 on Competition, of 3 July, and its regulation of 27 February 2008, which establishes a special procedure for arbitration.

29 The opening to arbitration is noticeable in regulated sectors, such as energy, oil and gas mainly, in other countries, i.e. Brazil, where in relation to concession contracts these resources are considered in the scope of free availability of the parties, since this is not a public service, according to the Brazilian constitution, allowing the Petroleum Law to submit disputes to arbitration, and also in the area of public-private partnerships (PPS) which expressly allows, in the contract model, the resolution of disputes between the concessionaire and the State, arbitration whose place of arbitration should Brazil and conducted in Portuguese language. See: J. A. Bucheb, A arbitragem internacional nos contratos da industria do petróleo, Lumen Juris 2002, 12-14; L. Da Gama e Souza, Jr., 121-157.

30 See P. Perales Viscasillas, "The role of arbitral institutions under the 2010 UNCITRAL Arbitration Rules“, Lima Arbitration, 6/2014, 26-76, http://www.limaarbitration.net/LAR6/Pilar_Perales.pdf, last visited 6 November 2017.

31 See: Royal Decree 657/2013, 30 August, on the Organic Rules to the National Commission on the Markets and Competition (BOE, No. 209, 31 August 2013):

\section{Arbitration function}

1. The National Market and Competition Commission may perform the functions of institutional arbitration, both in law and in equity, entrusted by the laws and those submitted voluntarily by economic operators, pursuant to Law 60/2003 on Arbitration, of 23 December.

2. The arbitration procedure shall conform to the principles of hearing, evidence, contradiction and equality and shall be subject to the rules of the United Nations Commission for Commercial Law or, as the case may be, those determined by the Council of the National Commission of Markets and Competition. An abbreviated procedure may also be envisaged depending on the level of complexity of the claim and its amount. 3. The Board of the National Market and Competition Commission is responsible for the administration of arbitration, each of the chambers being able to appoint arbitrators and determine the fees according to the tariffs approved by the Council. 


\section{GENERAL NOTIONS AND PRINCIPLES IN REGARD TO ARBITRABILITY IN SPAIN}

\subsection{The notion and functions of arbitrability}

The distinction between objective arbitrability (arbitrability rationae materiae, i.e. matters that can be settled by arbitration) and subjective arbitrability (authority and capacity) is adopted in the Spanish Arbitration Law (Art. 2), in line with the general trend among scholars ${ }^{32}$ and other arbitration laws.

Article 2.1 refers to objective arbitrability, considering the fact that all disputes relating to matters that may be freely disposed of by law can be settled by arbitration. The Spanish Law follows the general consideration under domestic laws of defining arbitrability under general standards. These general clauses require specification and interpretation in order to assess which of the specific issues related to a general matter are arbitrable. Although a case by case analysis is needed, generally speaking, in the field of commercial matters, most issues are arbitrable, as is also the case with civil matters, with the exception of certain family affairs. Furthermore, in very few cases, it is the law that confines the issues that are not subject to arbitration and thus establishes a clear line on the given matter. A clear example of that is Article 136 of the Patent Law (2015), which allows arbitration in regard to disputes on patents subject to the general rule on arbitrability (Art. 2.1 Arbitration Law). Furthermore this provision specifies the specific issues that are not arbitrable: "The matters relating to the concession, opposition or remedy procedures related to the titles regulated in this Law are not freely disposed, and the mediation or arbitration, when the object of the controversy is the fulfilment of the requirements for its grant, maintenance or validity". ${ }^{33}$ In addition, the Spanish body entrusted with the entire registered system (OEPM, Oficina Española de Patentes y Marcas) is allowed to function as an arbitral institution. ${ }^{34}$ Back to the general rule on arbitrability, it is

32 K. Sajko, "Arbitration Agreement and Arbitrability. Solutions and Open Issues in Croatian and Comparative Law", Croatian Arbitration Yearbook, 3/1996, 43 (some authors also refer to arbitrability ratione jurisdictionis); A. Uzelac, "New Boundaries of Arbitrability under the Croatian Law on Arbitration", Croatian Arbitration Yearbook 9/2002, 139 (referring also to arbitrability ratione institutionis).

33 For the scholars positions on the new Law on Patents, see: A. De Miguel Asensio, 81-101, with further references, considering that under Spanish law the better and prevailing view is that arbitrators may decide on issues of validity of industrial property rights, where validity arises in a context other than by principal claim and provided that the decision on validity only has an inter partes effect. Partial different view: P. Perales Viscasillas (2005b), 40.

34 See Article 3 of the Royal Decree No. 1270/1997, 24 July, as modified by the Patent Law. 
usually considered very broadly and in general terms that those rights that cannot be waived (Art. 6.3 Civil Code of Spain), as well as those related to the rights inherent to human beings, those which are at the same time a duty or linked to an obligation (state and capacity of persons, family law, etc.). Furthermore, also non-arbitrable are those that affect third parties etc., while, as a rule, the patrimonial relations are arbitrable. ${ }^{35}$

Subjective arbitrability has a special rule in regard to international arbitration and when one of the parties is a state or company, organization, or enterprise controlled by a state, where that party may not avail itself of the privileges of its domestic law to avoid its obligations under the arbitration agreement. ${ }^{36}$ The intention, as recognised in the Preamble of the Arbitration Law, is that a state shall be treated exactly the same as a private party. To this regard, Royal Legislative Decree 3/2011 on Administrative Contracts, of 14 November, provides that when the contracts are concluded and executed outside Spain, the inclusion of an arbitration clause is recommended. As international and domestic practice reveals, it is not uncommon for some states to invoke the non-arbitrability of the question submitted to arbitration in order to escape the arbitration agreement, in the understanding that the matter is not subject to arbitration under national law on grounds of public policy. ${ }^{37}$

In Spain, where the entire system of arbitration is based upon a voluntarily arbitration, as opposed to a mandatory arbitration, a notion of arbitrability is needed in order to draw a line between the matters that might be subjected to arbitration. Also, from the Spanish perspective it is up to the State to decide what matters are arbitrable, and thus to exclude or include matters from the scope of the subject matter of arbitrability. Therefore, it is not for the parties to decide the definition or scope of arbitrability in the arbitration agreement, and thus they cannot transform a matter that is not arbitrable into an arbitrable one, merely by their desire. Thus, an arbitration agreement over an non-arbitrable matter is invalid and the arbitrators cannot render a valid arbitration award. What the parties are able to do is to limit the scope of the issues that may be the object of arbitration, and thus an arbitrable matter may be excluded by the wish of the parties as expressed in the arbitration agreement.

35 STSJC 4/02/2016 (M. Eugenia Alegret) (No. 3/2014).

36 Article 2 (2) of the Spanish Arbitration Act: 2. In international arbitration, when one of the parties is a State or a State-controlled company, organisation or enterprise, that party may not invoke prerogatives of its own law to circumvent obligations stemming from the arbitration agreement.

For a description of the immunity of States under Spanish Law see: Juzgado de Primera Instancia de Madrid, 5 September 2016 (No. 394/2016).

37 See: R. S. Grion, "Breves notas sobre a participação do Estado em Arbitragem Comercial. Arbitragem e comercio internacional”, Estudos em homenagem a Luiz Olavo Baptista, Quartier Latin do Brasil, 2013, 863. 
3.2. A general policy principle that favours arbitrability under Spanish Law

Some scholars have considered that under Spanish Law the specific application of the principle of favour arbitris to arbitrability means that there is a general presumption in favour of the arbitrability of commercial disputes (policy favouring arbitrability); ${ }^{38}$ and also that there is a clear tendency to expand the scope of the subject-matter of arbitration as considered in the previous section (supra II). The principle of favouring arbitrability is seen under Art. 9.6 Law 60/2003, applicable to international arbitration, which considers that the matter is subject to arbitration if admitted under any of the following laws: rules of law chosen by the parties to deal with the arbitration agreement or the contract, or by Spanish Law. ${ }^{39}$ One example is the insolvency law. Initially, the insolvency law of 2003 considered that without the prejudice of international treaties, the arbitration agreements to which the debtor was a party would have neither value nor effect during the insolvency procedure (Art. 52). ${ }^{40}$ Further, Law 11/2011 tried to adapt Art. 52 of the Insolvency Law to the European Union solutions (Regulation 1346/2000) and to eliminate the incoherence between paragraphs 1 and 2 of Art. 52, which were object of severe criticism by scholars. The singularity of the Spanish insolvency law, in regard to arbitration, was highly criticised by scholars, and so the new regulation has to be assessed. According to the new regulation, ${ }^{41}$ the declaration of the in-

38 B. Hanotiau, "L`Arbitrabilité et le favor arbitrandum: un réexamen”, Journal du Droit International 1994, 899; G. Born, International Arbitration: Law and Practice, Wolters Kluwer Law \& Business, 2012, 82.

39 Article 9 (6) of the Spanish Arbitration Act (2003) whereby: "When the arbitration is international, the arbitration agreement shall be valid and the dispute may be subject to arbitration if the requirements stipulated by the law chosen by the parties to govern the arbitration agreement, the law applicable to the substance of the dispute, or Spanish law, are fulfilled."

40 Article 52 of the Arbitral Procedures. "1. The arbitration agreements in which the debtor is a party shall have no value or effect during the procedure of insolvency, without prejudice to the provisions of international treaties.

2. The arbitration proceedings in process at the time of the declaration of insolvency will continue until the finality of the award, being applicable the rules contained in paragraphs 2 and 3 of the previous article."

For the rule that was applied strictly: see Auto Appellate Court of Barcelona, 29 April 2009, with a critic commentary by I. H. Cervantes, Revista de Arbitraje Comercial $y$ de Inversiones 3/2010, 841-849.

41 Article 52 of the Arbitration Proceedings.

"1. The declaration of insolvency proceedings alone does not affect mediation clauses or arbitration agreements signed by the insolvent debtor. When the jurisdictional body understands that such clauses or agreements may cause harm to the process of the insolvency proceedings, it may rule to suspend their effects, without prejudice to the provisions set forth in the international treaties. 
solvency proceedings, in itself, does not affect the arbitration or conciliation agreements concluded by the insolvent. However, without the prejudice of international agreements, the insolvency court might suspend the effect of the agreements if it considers them to be an obstacle for the insolvency proceedings. It is worth mentioning that the new provision also refers to the conciliation agreements and not only to arbitration agreements, which was the previous rule. The system is completed with a special rule for consumer arbitration. ${ }^{42}$ Despite this general policy favouring arbitrability, recent court decisions in Spain have considered that a maximalist standard of review applies when setting aside an award due to the non-arbitrability of the subject matter of the dispute, i.e. the court can fully review the facts and the law as considered by the Arbitral Tribunal. ${ }^{43}$

\section{OBJECTIVE ARBITRABILITY: SOME RESTRICTIONS AT LAW}

As considered earlier, the general provisions on arbitrability under Art. 2 of the Spanish Arbitration Act need to be interpreted in order to assess whether specific disputes are arbitrable. Despite this modern approach to arbitrability already seen, some recent limitations to party autonomy, either minor, such as it will be seen in the case of corporate arbitration, or of a broader range, by restricting objective arbitrability of the dispute,

2. Arbitration proceedings in progress at the moment of declaring the insolvency proceedings open shall continue until the award is final, the rules set forth in Paragraphs 2 and 3 above being applicable.

Article 53 of the Final Court Rulings and Arbitration Awards:

1. The final rulings and awards handed down before or after the declaring open insolvency proceedings shall be binding to the Court of the latter, which shall hand down the decisions for the appropriate insolvency treatment.

2. What is set forth in this Article is understood to be notwithstanding the right of the insolvency practitioners to contest arbitration bonds and proceedings in the event of fraud."

For further references see: M. F. Martín Moral, El concurso de acreedores y el arbitraje, La Ley/Wolters Kluwer 2014; P. Perales Viscasillas, "Artículos 52 y 53 de la Ley Concursal", Comentario a la Ley Concursal, La Ley/Walters Kluwer, Madrid 2016, 698-711.

42 See Article 58 (2) of the General Law on Consumers: "Arbitration agreements and public offerings of adhesion to consumer arbitration, where made by those who have been declared subject to bankruptcy proceedings, shall be invalid. For such purposes, the notice of commencement of bankruptcy proceedings shall be communicated to the body through which the agreement was drawn up, and to the National Consumer Arbitration Board, with the debtor subject to bankruptcy proceedings excluded from the Consumer Arbitration System, for all purposes, from this time."

43 Among others, STSJ de Madrid, 3 November 2015 (No. 7/2015). 
excluding arbitration before the dispute has arisen, excluding it through the imposition of the exclusive jurisdiction of the State Courts, or judicial decisions (infra V), threaten this optimistic view about arbitrability in Spain.

\subsection{Corporate Arbitration}

Very few statutes address arbitrability in regard to corporations. Some link arbitrability with the general standards provided in arbitration laws, however, others consider a wider scope of issues, sometimes limiting the scope of arbitrability to certain intra-corporate disputes or limiting the persons subject to arbitration. Although since the 2011 reform of the Spanish Arbitration Act, Spain expressly allows arbitration for corporations (closed corporations and publicly-held corporations), ${ }^{44}$ confirming an approach favourable to arbitration, ${ }^{45}$ ad hoc arbitration in case of challenges to corporate resolutions is, in principle, prohibited. Furthermore it is required that all arbitrators be appointed by the institution. Moreover, the Spanish Arbitration Act (Art. 11 bis and ter) requires a supermajority vote of shareholders for the introduction of an arbitration clause into corporate bylaws and does not recognise the appraisal rights of dissenters, in contrast to other national legislations, such as in Italy, ${ }^{46}$ where dissenters have appraisal rights, and under the Mauritius International Arbitration Act, where a unanimous vote of current shareholders is required (Section 3(6)). Under Spanish Law, arbitration is allowed both in equity and in law, ${ }^{47}$ as opposed to Italian Law, which forbids arbitration in equity. ${ }^{48}$

44 In contrast, Italian law forbids it (Legislative Decree of 17 January 2003, No. 5).

For Italian scholars see: L. Boggio, Deliberazioni assemblearie "diritti disponibili relative al rapport sociale”, EDUCatt, 2012.

45 STSJ Castilla-La Mancha, 24 November 2016 (No. 13/2016) and STSJM, 9 February 2016 (No. 15/2016).

46 Legislative Decree of 17 January 2003, No. 5 as amended further, Title V - On Arbitration.

For a comparative analysis of Italy and Spain, see the different papers at: L'arbitrato societario in Spagna e in Italia. Un analisi comparata, Giurisprudenza Italiana 6/2014, $1522-1544$.

47 Same position in Chile, where a complex arbitration rules are interpreted in a very different way by scholars. See: E. Jequier Lehuedé, "El arbitraje en el Derecho Chileno de Sociedades", Arbitrabilidad del conflicto societario mercantile, Thomson/Reuters, 2013, 322-323.

48 Other limitations seen at a comparative level include, for example, the Arbitration Law of Mauritius, which requires the juridical seat of any arbitration under the Act to be Mauritius. Italian law requires all arbitrators to be appointed by a third person unrelated to the company, and requires the request for arbitration to be publicly registered and available for inspection. Italian law also allows third-party intervention, in which the award is binding on the company, even if the company was not party to the arbitration. Finally, in contrast with to Italy's general arbitration act, which does not give arbitrators the power to issue interim measures of protection, arbitrators do have this power in regard 
A good legislative and doctrinal approach to arbitration and arbitrability exists in Brazil where the doctrine favours both arbitration in the capital and financial markets, and in corporate arbitration in general, already permitted in the former Art. 294 of the Commercial Code, and especially after the Modification of the Law for Corporations, of 31 October 2001 (Law 10.303/2001), where article 109, paragraph 3 states that: "The company's bylaws may establish that the divergences between shareholders and the company, or between the Controlling shareholders and minority shareholders, may be settled through arbitration, under such terms as may be specified". ${ }^{49}$ Arbitration, which from the point of view of objective arbitrability, is broadly understood in line with Article 1 of the Arbitration Law of Brazil, in such a way that it is affirmed that all the rights inherent to the shareholder status are patrimonial, including the right to vote, ${ }^{50}$ and even for those authors who conclude the need to examine each situation on a case by case basis, consider there to be a general principle of arbitrability of corporate issues. ${ }^{51}$ Among the very few exceptions considered by scholars are issues related to the nullity of decisions taken at a general meeting, due to their close connection with public order, but those relating to annulability would be arbitrable. ${ }^{52}$

\subsection{Consumer Arbitration}

In regard to arbitration agreements in consumer situations, Spanish Consumer Arbitration agreements were modified in compliance with Art. 10 of Directive 2013/11, of the European Parliament and of the Council, on Alternative Dispute Resolution for Consumer Disputes, of 21 May

to intra-corporate disputes according to Article 23 of the Spanish Arbitration Act, including the recognized possibility of issuing ex parte interim measures. See STJ of Cataluña, 7 April 2016 (Carlos Ramos Rubio) (No. 22/2015), considering valid an interim measure ex parte, something that was expressly allowed by the arbitration rules, but also considered - wrongful, in our opinion, by analogy with the powers that a judge would have under the civil procedural law.

49 See: U. Caminha, "Arbitragem como instrumento de desenvolvimento do mercado de capitais", Aspectos da arbitragem institucional. 12 anos da Lei 9.307/1996, Malheiros editores 2008, 93-114; D. Andrade de Levy, "Estudo comparado da arbitragem no mercado de capitais", Revista de Direito Mercantil, industrial, económico e financiero 155/156/2010, 275-300, especially, 286-288, in regard to objective arbitrability.

50 A. Goes Acerbi, "A extensão dos efeitos da cláusula compromissória nos estatutos das Sociedades Anônimas", Aspectos da arbitragem institucional. 12 anos da Lei 9.307/1996, Malheiros editores 2008, 189-193; D. Franzoni, Arbitragem Societária, Thomson/Reuters, 2015, 102-122.

51 P. A. Batista Martins, Arbitragem no direito societário, Quartier Latin, 2012, 177-185.

52 A. Goes Acerbi, 192-193. Oppositely, considering nullity issues arbitrable: P. A. Batista Martins, 204-210. 
2013, 2013 O.J. (L 165/63) (EU). ${ }^{53}$ According to the old system, predispute arbitration clauses in Law 1/2007 (Art. 57.4), as well as agreements to arbitrate, contained in general conditions governed by Law 1/2007 (Art. 90), were binding for consumers if the provided arbitration system was the special consumer arbitration system created by the State and regulated under the consumer arbitral system (i.e. the one contained in Royal Decree 231/2008). Now, under the new Art. 57.4, as modified by Law 3/2014, any arbitration agreement concluded before the dispute is not binding for the consumer, but it binds the merchant if the consumer later accepts it, and when another condition is met: the arbitration agreement should meet the conditions required by the applicable laws. ${ }^{54}$

\subsection{The exclusive jurisdiction of State the Courts}

Public policy should not be confused with mandatory rules. In modern judicial application, it is clear today in Spain that even if a matter is subject to mandatory rules, it may be subject to arbitration with the obligation of arbitrators to respect those rules. ${ }^{55}$ Whether the public order impedes the submission of a dispute to arbitration is usually a question to be decided by the law or by judicial interpretation, as the case may be.

In regard to the exclusive jurisdiction of state courts, an evolution in favour of arbitrability might be seen in Spain. ${ }^{56}$ Generally, it is said,

53 The general Law on Consumers (Ley General para la Defensa de los Consumidores y Usuarios, Law 1/2007) was modified by Law No. 3/2014, B.O.E., 2014, 3.

54 Presently, Article 57 (4) of Law 1/2007, as amended by Law 3/2014, states that: "Consumer arbitration agreements other than those stipulated in this article may only be agreed on once the material conflict or dispute between the contractual parties has arisen, except in cases of submission to institutional arbitration bodies created by laws or regulations for a sector or a specific eventuality. Arbitration agreements negotiated in contravention of the provision of the preceding paragraph shall be null and void."

And for the arbitration clauses in general terms of conditions in consumer relations, see Article 90: "Terms that establish the following shall also be deemed unfair: 1. Submission to arbitration other than consumer arbitration, except where this involves institutional arbitration bodies created by law for a specific circumstance or sector." For further details, see P. Perales Viscasillas (2014), 22.

55 For all: STSJM, 19 January 2016 (Santos Vijande) (No. 39/2015).

56 A more restrictive view on arbitration has been adopted by certain legal systems that consider both pre- and post-dispute arbitration clauses to be invalid, because in these jurisdictions only the state courts are considered competent to hear a dispute. Therefore, arbitration as a means to solve disputes is pre-empted by imposing the exclusive jurisdiction of state courts. An example is the Code of Private International Law of the Republic of Panama (8 May 2014). Belgium is another example of a jurisdiction where legislation provides for the exclusive jurisdiction of the state courts, as well as for the mandatory application of state law in certain distribution contracts and agency contracts. Belgian case law tends to apply Article II(3) of the 1958 New York Convention on the Recognition and Enforcement of Foreign Arbitral Awards and, thus, Belgian courts have found that arbitration agreements are null and 
that for reasons of legislative policy, the State may assign certain issues to a special jurisdiction. In such case, it will be the law that indicates the administrative or judicial body, other than the regular authority, that is responsible for the resolution of disputes, which will also not be able to arbitrate those matters whose resolution is entrusted exclusively to the jurisdiction or the administrative authority of the State or, likewise, there is an imperative attribution of jurisdiction. ${ }^{57}$

\section{RECENT CASE LAW RESTRICTING OBJECTIVE ARBITRABILITY}

In the area of regulated sectors, specifically the gas sector, a July 2015 decision by the Superior Court of Justice of Madrid (Tribunal Superior de Justicia), the competent court to decide on the setting aside of an award when the seat of the arbitration is Madrid, declared non-arbitrable a dispute between two multinational Spanish operators in the natural gas sector. The dispute arose over the system operator and carrier's refusal to renounce the reserved capacity in its contract to transport gas to FranceLarrau. The Court considered this issue non-arbitrable and cancelled the partial award on arbitrability and jurisdiction, due to the need to preserve the public interest in a strategic and regulated sector. Whether a different result might have been reached in an international dispute is uncertain even with the application of Art. 9.6 of the Spanish Arbitration Act, which considers the applicable law to arbitrability under a pro-arbitration rule for international arbitrations: the matter is subject to arbitration if allowed under either the rules of law chosen by the parties to deal with the arbitration agreement, the law applicable to the contract, or under Spanish Law. Furthermore, there are no decisions in Spain denying the exequatur of an arbitral award, due to non-arbitrability of the subject-matter of the dispute under the NYC. ${ }^{58}$ The arbitrability of disputes concerning regulated sectors is quite controversial and complex, because key institutions involved: arbitration, state justice and decision-making powers attributed to a regulatory body, in the case of Spain, the National Commission on Markets and Competition (CNMC). The following lines are not intended to address this issue completely, since arbitration of regulated sectors and the conflicts that may arise covers a very broad field, especially at an international level, including, from the disputes between regulators, between

void because of the exclusive competence of state courts. See P. Perales Viscasillas (2015), 213.

57 STSJC 4/02/2016 (M.Eugenia Alegret) (No. 3/2014).

58 Vicente L. Montes, "Algunas cuestiones en torno a la "inarbitrabilidad de la diferencia' en el exequátur de laudos extranjeros", Spain Arbitration Review 5/2009, $13-14$. 
them and regulated subjects, between regulated subjects, and between any of the above and consumers. The purpose is more modest, so we will focus the analysis of the non-arbitrability of the disputes in the international transits of gas, i.e. the reduction of contracted capacity - by the STSJM, 13 July 2015 ( $\mathrm{n}^{\circ}$ 5/2015). ${ }^{59}$ The STSJM, 13 July 2015, analyses the arbitrability nature of the disputed matter, namely the reduction of the capacity contracted at the point of departure of the international connection from Larrau, Spain to France. The STSJM makes the following considerations of interests in matters of arbitrability:

a) The court aptly referred to the point at which arbitrability should be examined, which is important since arbitrability is a variable criterion over time, hence, as indicated by the court, when Article 2 of the Law of arbitration refers to the arbitrability of the dispute places the decisive moment to define arbitrability at the moment when the claims are determined, rather than the moment when the arbitration agreement is concluded.

b) The Court rejected that the free availability enshrined in article 2.1 LA is synonymous with patrimoniality, which was actually the solution found by the arbitrators in the awarding the object of the dispute. Leaving aside the fact that the decision cannot be made automatically, the fact is that the two criteria mentioned are not identical, the question being, however, whether free availability is broader or narrower than the criterion of patrimonial matters. When dealing in both cases with indeterminate concepts, putting them into practice will be difficult.

Determining the meaning of the criterion of free availability under Spanish Law is unquestionably complex because the legal criterion is indeterminate, amorphous, elastic and unclear. It is true, as the TSJM argues, that the attribution of competence to resolve a dispute may, in line with the circumstances, clearly indicate the arbitrability or non-arbitrability of the subject matter in question. In other words, the non-arbitrability of the dispute may derive not only from the material aspect of the dispute (dispute over the conditions of use of gas infrastructure which for the Court is a matter that it is affected by public order, the general interest, and because it affects third parties rights, with the need not to confuse

59 Comments by: L. García del Río, "Notas sobre la arbitrabilidad de disputas relacionadas con materias de derecho público a raíz de la sentencia dictada en el Asunto Larrau", Revista la Ley Mercantil 27/2016, 8; B. De Paz Gútiez, "Las recientes sentencias del Tribunal Superior de Justicia de Madrid en relación con la arbitrabilidad de las controversias surgidas en contratos del sector del gas natural", Spain Arbitration Review/Revista del Club Español del Arbitraje, 26/2016, 40; P. Perales Viscasillas, "Arbitraje y arbitrabilidad de las controversias en el sector gasista", Revista del Club Español del Arbitraje/Spain Arbitration Review 29/2017, 9-42. 
public order with imperative rules), but also from the jurisdictional aspect of the dispute, by granting exclusive jurisdiction to a particular body, which in the case at hand is the CNMC. In the opinion of the TSJM, in the case under consideration both types of circumstances are met and thus the dispute was considered non-arbitrable, and so the partial award on jurisdiction was dismissed. For the former, the TSJM without many interpretative efforts successively lists various references and rules from EU regulations, from which, we will not deny, it derives the importance of the internal gas market, the protection and promotion of free competition, security of supply, and the benefits of regulations for consumers, among others. furthermore, if we consider the arguments expressed by the TSJM in regard to material non-arbitrability, i.e. defence of competition, security of supply, general interest, etc., we will also find that they are met in general in the gas system - and of course in many other sectors (competition law, company law and others) so that ultimately no question or controversy that could arise within them could be submitted for arbitration and this would mean leaving out contracts in the upstream sector, for example, where gas arbitration is a regular situation. ${ }^{60}$ For the latter, it is necessary to consider that the CNMC, as a regulatory body, has two different dispute functions: administrative and arbitral. The first one is considered in article 12 (b) of Law 3/2013, of 4 June, establishing the National Market Commission and the Competition whereby it resolves disputes brought to it by economic operators in the electricity and gas markets. In this case, the CNMC resolves disputes subject to further appeal before the administrative judiciary, as opposed to the arbitration activity of the CNMC, which is entirely private in nature and thus there is no appeal against the award.

60 V. Ben Holland, J. Wilson, "Tailoring the arbitral process to suit natural gas Price reviews: the case for two-stage final offer arbitration", Int. A.L.R. 16/2013, 81-87; VVAA, Gas Price Arbitrations: A practical handbook, Globe Business Publishing, 2014; J. P. Wilheim, "The Arbitration Agreement and Arbitrability, The Powers of Arbitral Tribunals in Price Revision Disputes Illustrated with the Example of Long Term Gas Supply Agreements", Austrian Yearbook on International Arbitration 2014, 17-29; A. Mourre, "Gas Price Reopeners: Is Arbitration Still the Answer?", Disp. Resol. Int'l 9/2015, 139-147; M. Clarke, T. Cummins, F. Worthington, "The price isn't right - gas pricing disputes", International Energy Law Review 1/2015, 13-20; P. Ferrario, The Adaptation of Long-Term Gas Sales Agreements by Arbitrators, Wolters Kluwer, 2017.

Interesting are the statistics of the Stockholm Chamber of Commerce: "Supply contracts are the most commonly disputed gas contracts, accounting for $75 \%$ of the gasrelated arbitrations administered by the SCC. $19 \%$ of the gas-related disputes have involved contracts for the exploration and development of gas fields, while $6 \%$ involved a consultancy agreement": A. Magnusson, "The SCC Experience of Gas Disputes:Perspectives from a Leading Arbitration Centre", Second Annual Forum on Commercial \& Legal Strategies for Successfully Negotiating Long Term Gas Supply Contracts, 13-14 June 2012 Berlin, 4, http://www.sccinstitute.com/media/30005/mag nusson_gasdisputes_ thescc_experience.pdf, last visited 6 November 2017. 
Whether the CNMC functions as a court of arbitration administering the cases or as an arbitrator is highly controversial in $\mathrm{Spain}^{61}$ and similarly abroad, because of the breach of the neutrality principle in arbitration. Recently this issue has recently been addressed, at the level of legal interpretation, by the Judgment of the High Court of Justice of Madrid (TSJM), 20 December 2016, nr. 69/2016, where the court clarifies that the arbitration function of the CNMC reaches also the function and role of an arbitrator and thus the issuing of awards. Therefore its function cannot be solely that of mere administrator of the arbitration, but can consequently act as an arbitrator. Where to define the border between conflicts that are subject to the administrative power of the CNMC and those that are subject to private arbitration is not easy to decide, and thus it will be necessary for future legislation to help provide clarity and certainty in this area.

\section{REFERENCES}

Andrade de Levy, D., "Estudo comparado da arbitragem no mercado de capitais", Revista de Direito Mercantil, industrial, económico e financiero 155/156/2010.

Batista Martins, P. A., Arbitragem no direito societário, Quartier Latin, 2012.

Boggio, L., Deliberazioni assemblearie "diritti disponibili relative al rapport sociale”, EDUCatt, 2012.

Born, G., International Arbitration: Law and Practice, Wolters Kluwer Law \& Business, 2012.

Bouza Vida N., "La arbitrabilidad de los litigios en la encrucijada de la competencia judicial internacional y de la competencia arbitral", Revista Española de Derecho Internacional 2/2000.

Bucheb, J. A., A arbitragem internacional nos contratos da industria do petróleo, Lumen Juris, 2002.

Caminha, U., "Arbitragem como instrumento de desenvolvimento do mercado de capitais", Aspectos da arbitragem institucional. 12 anos da Lei 9.307/1996, Malheiros editors, 2008.

Cervantes, I. H., Revista de Arbitraje Comercial y de Inversiones 3/2010. Clarke, M., Cummins, T., Worthington, F., "The price isn't right -gas pricing disputes", International Energy Law Review 1/2015.

61 P. Perales Viscasillas, "La función arbitral de la Comisión Nacional de los Mercados y de la Competencia", La Ley Mercantil, Sección Arbitraje mercantil 14/2015, 1-55; C. González Pulido, "Puede la CNMC decidir no administrar un arbitraje si las partes la han elegido como institución administradora pero considera que la disputa es no arbitrable?", Revista Derecho Competencia y Distribución 19/2016, 10. 
Da Gama e Souza, L. Jr., "Sinal verde para a arbitragem nas parcerias público-privadas (A Construção de um novo paradigma para os contratos entre o Estado e o Investidor privado)", Revista de Direito Administrativo 2/2005.

De Lima Pinheiro, L., Arbitragem Transnacional. A determinação do estatuto da arbitragem, Almedina-Coimbra 2005.

De Miguel Asensio, A., "Alcance de la arbitrabilidad de los litigios sobre derechos de propiedad industrial", Arbitraje 1/2014.

De Paz Gútiez, B., "Las recientes sentencias del Tribunal Superior de Justicia de Madrid en relación con la arbitrabilidad de las controversias surgidas en contratos del sector del gas natural", Spain Arbitration Review/Revista del Club Español del Arbitraje 26/2016.

Ettore Nanni, G., Direito Civil e Arbitragem, Atlas, Sao Paulo 2014.

Ferrario, P., The Adaptation of Long-Term Gas Sales Agreements by Arbitrators, Wolters Kluwer, 2017.

Franzoni, D., Arbitragem Societária, Thomson/Reuters, 2015.

García del Río, L., "Notas sobre la arbitrabilidad de disputas relacionadas con materias de derecho público a raíz de la sentencia dictada en el Asunto Larrau", Revista la Ley Mercantil 27/2016.

Goes Acerbi, A., "A extensão dos efeitos da cláusula compromissória nos estatutos das Sociedades Anônimas", Aspectos da arbitragem institucional. 12 anos da Lei 9.307/1996, Malheiros editores, 2008.

González Pulido, C., "Puede la CNMC decidir no administrar un arbitraje si las partes la han elegido como institución administradora pero considera que la disputa es no arbitrable?", Revista Derecho Competencia y Distribución 19/2016.

Grion, R. S.,"Breves notas sobre a participação do Estado em Arbitragem Comercial. Arbitragem e comercio internacional", Estudos em homenagem a Luiz Olavo Baptista, Quartier Latin do Brasil, 2013.

Hanotiau, B., "L'Arbitrabilité et le favor arbitrandum: un réexamen", Journal du Droit International 1994.

Holland, B., Wilson, J., "Tailoring the arbitral process to suit natural gas Price reviews: the case for two-stage final offer arbitration", Int. A.L.R. 16/2013.

Jequier Lehuedé, E., "El arbitraje en el Derecho Chileno de Sociedades", Arbitrabilidad del conflicto societario mercantile, Thomson/Reuters 2013.

Justino de Oliveira, G. H., "A Arbitragem e as Parcerias Público-Privadas", Revista de Direito Administrativo 2005.

Kleinheisterkamp J., "The Impact of Internationally Mandatory Law on the Enforceability of Arbitration Agreements", LSE Law Society and Economic Working Papers 22/2009. 
Kröll, S., "The 'Arbitrability' of disputes arising from Commercial Representation", Arbitrability. International \& Comparative Perspectives, Wolters Kluwer, 2009.

Magnusson, A., "The SCC Experience of Gas Disputes:Perspectives from a Leading Arbitration Centre", Second Annual Forum on Commercial \& Legal Strategies for Successfully Negotiating Long Term Gas Supply Contracts, 13-14 June 2012 Berlin, 4, http://www.sccinstitute.com/media/30005/magnusson_gasdisputes_thescc_experience.pdf.

Malheiros Duclerc Verçosa H., "Doze anos da lei de arbitragem: alguns aspectos ainda relevantes", in Aspectos da arbitragem institucional. 12 anos da Lei 9.307/1996, Malheiros editors, 2008.

Martín Moral, M. F., El concurso de acreedores y el arbitraje, La Ley/ Wolters Kluwer, 2014.

Menezes Cordeiro A., Tratado da Arbitragem. Comentário à Lei 63/2011, de 14 de Dezembro, Almedina-Coimbra 2015.

Montes, V. L., "Algunas cuestiones en torno a la 'inarbitrabilidad de la diferencia' en el exequátur de laudos extranjeros", Spain Arbitration Review 5/2009.

Mourre, A., "Gas Price Reopeners: Is Arbitration Still the Answer?", Disp. Resol. Int'l 9/2015.

Penteado, C. M. C. Jr., "Os Direitos patrimoniais disponíveis e as regras de julgamento na arbitragem", Revista de Arbitragem e Mediação 20/2009.

Perales Viscasillas, P., "Arbitrabilidad de los derechos de la propiedad industrial y de la Competencia", Anuario de Justicia Alternativa, Derecho Arbitral 6/2005.

Perales Viscasillas, P., "Arbitraje y arbitrabilidad de las controversias en el sector gasista", Revista del Club Español del Arbitraje/Spain Arbitration Review 29/2017.

Perales Viscasillas, P., "Artículos 52 y 53 de la Ley Concursal", Comentario a la Ley Concursal, La Ley/Walters Kluwer, Madrid 2016.

Perales Viscasillas, P., "La función arbitral de la Comisión Nacional de los Mercados y de la Competencia", La Ley Mercantil, Sección Arbitraje mercantil 14/2015.

Perales Viscasillas, P., "Los convenios arbitrales con los consumidores (La modificación del art. 57.4 TRLGDCU por la Ley 3/2014 de 27 de marzo)", La Ley Mercantil 7/2014.

Perales Viscasillas, P., "The Good, the Bad, and the Ugly in Distribution Contracts: Limitation of Party Autonomy in Arbitration?", Penn. St. J.L. \& Int'l Aff 4/2015. 
Perales Viscasillas, P., "The role of arbitral institutions under the 2010 UNCITRAL Arbitration Rules", Lima Arbitration, 6/2014, http:// www. limaarbitration.net/LAR6/Pilar_Perales. $p d f$.

Perales Viscasillas, P., Arbitrabilidad y Convenio arbitral (Ley 60/2003 de Arbitraje y Derecho Societario), Thomson-Aranzadi, Navarra 2005.

Richard González M., Riaño Brun I., Rifá Soler, J. M., Estudios sobre arbitraje de consumo, Thomson Reuters, 2011.

Sajko, K., "Arbitration Agreement and Arbitrability. Solutions and Open Issues in Croatian and Comparative Law", Croatian Arbitration Yearbook 3/1996.

Talamini, E., "A (in) disponibilidade do interesse público: conseqüências processuais (composições em juízo, prerrogativas processuais, arbitragem e ação monitória", Revista de Processo 128/2005.

Trabuco, C., Francça Gouveia, M., "A Arbitrabilidade das questões de concorrência no direito portugués: The meeting of the two black arts", Estudos em homenagem ao Professor Doutor Carlos Ferreira de Almeida, Almedina 2011.

Uzelac, A., "New Boundaries of Arbitrability under the Croatian Law on Arbitration", Croatian Arbitration Yearbook 9/2002.

Vicente D. M., Law of Voluntary Arbitration Annotated, Almedina - Coimbra 2017.

VVAA, Gas Price Arbitrations: A practical handbook, Globe Business Publishing, 2014.

Wilheim J. P., "The Arbitration Agreement and Arbitrability, The Powers of Arbitral Tribunals in Price Revision Disputes Illustrated with the Example of Long Term Gas Supply Agreements", Austrian Yearbook on International Arbitration 2014.

Zimmermann, D., "Alguns aspectos sobre a arbitragem nos contratos administrativos à luz dos principios da eficiencia e do acceso à justiça, por uma nova concepção do que seja interesse público", Revista de Arbitragem e mediaçao 2/2007.

Article history:

Received: 7. 11. 2017. Accepted: 29. 12. 2017. 